\title{
Study on the growth performance of the broiler after feeding of okara meal containing with or without non-starch polysaccharides degrading enzyme
}

\author{
Subodh Kumar Sinha, Ajit Kumar Sinha, Deepak Kumar Mahto and Rajeev Ranjan ${ }^{1}$ \\ Ranchi Veterinary College, Ranchi, Birsa Agricultural University, Jharkhand - 6, India \\ 1. Project Directorate on Foot and Mouth Disease, Mukteswar, UP, India \\ Corresponding author: Subodh Kumar Sinha, email:subodh_rvc@yahoo.co.in \\ Received: 31-09-2012, Accepted: 05-10-2012, Published online: 12-03-2013
}

How to cite this article: Sinha SK, Sinha AK, Mahto DK and Ranjan R (2013) Study on the growth performance of the broiler after feeding of okara meal containing with or without non-starch polysaccharides degrading enzyme, Vet. World 6(6):325328, doi: 10.5455/vetworld.2013.325-328

\begin{abstract}
Aim: The objective was to study the growth performance of the broiler birds after feeding Okara meal containing with or without non-starch polysaccharides degrading enzyme.

Materials and Methods: 220 day-old broiler chicks were individually weighed and divided randomly into five treatment groups $\left(\mathrm{T}_{1}, \mathrm{~T}_{2}, \mathrm{~T}_{3}, \mathrm{~T}_{4}\right.$ and $\left.\mathrm{T}_{5}\right)$ consisting of 44 chicks each which was further subdivided into four replicates of 11 chicks. The feed consumption in each replicates of five groups was recorded daily for a total period of 6 weeks experimental feeding.

Results: The average total feed consumption of six weeks was $3948.10 \pm 7.60,4088.76 \pm 8.30,4415.33 \pm 9.44,4381.24 \pm 9.25$ and $4728.76 \pm 10.05(\mathrm{~g})$ in groups $\mathrm{T}_{1}, \mathrm{~T}_{2}, \mathrm{~T}_{3}, \mathrm{~T}_{4}$ and $\mathrm{T}_{5}$, respectively. The differences were statistically non-significant $(\mathrm{P}>0.05)$ among the various groups. The average total body weight gain and average daily weight gain in birds of group $\mathrm{T}_{4}$ were significantly higher $(\mathrm{P}<0.01)$ than birds of other groups except $\mathrm{T}_{3}$ group. It showed that 25 percent replacement of ground nut cake with Okara meal and addition of non-starch polysaccharides degrading enzyme (provizyme-bro) had positive effect on growth performance of birds. The increase in weight in broilers of enzyme added group $\mathrm{T}_{4}$ in comparison to their counterpart without enzyme group $\left(T_{2}\right.$ and $\left.T_{3}\right)$ attributed to degradation of non-starch polysaccharides in ration, thereby, enhancing the utilization of other nutrients.
\end{abstract}

Conclusion: The findings indicated that 25 percent replacement of ground nut cake with Okara meal and addition of nonstarch polysaccharides degrading enzyme had positive effect on growth performance of birds. So, Okara meal feeding had no adverse effect on growth performance of the broilers.

Key words: broiler birds, degrading enzyme, groundnut cake, growth performance, non-starch polysaccharides, Okara meal

\section{Introduction}

Feeding has been recognized as an important aspect as it accounts for 70-75 percent of the total cost of poultry production [1], which is possible only by using locally available feed ingredients and agroindustrial byproducts. Soybean is a legume which is well-known for its beneficial properties [2]. Soybean contains 40 per cent high quality proteins, 20 per cent oil, dietary fiber and photochemical, as well as, number of minerals, vitamins and has the best essential amino acid profile, but it is deficient in sulfur-containing amino acids (methionine, lysine, cystine) and contains endogenous anti-nutrients including protease (trypsin) inhibitors [3]. Because of their versatile applications, soybeans have played important roles in feed industries. This plant having tonic and restorative food properties because of its high content of isoflavone, a compound whose chemical structure is similar to that of estrogen [4]. This soy-derived food has several potential health benefits viz. cardiovascular diseases,

This article is an open access article licensed under the terms of the Creative Commons Attribution License (http://creativecommons. org/licenses/by/2.0) which permits unrestricted use, distribution and reproduction in any medium, provided the work is properly cited. osteoporosis, breast and prostate cancers because they are rich sources of bioactive phenolic compounds [5].

Okara is a byproduct of soymilk processing which contains shell, hull or husk of ground soybean [6]. It is beige in color and has a light, crumbly, fine grained texture, which makes it look like moist sawdust or grated coconut and tastes similar to almond [7]. Okara is rich in dietary fibre, mainly as insoluble fibre, besides protein and fat [8-11]. Okara from soyabean, like most vegetable residues from the food industry, is very rich in insoluble but has a low soluble dietary fibre content $[8,10]$. Okara is just treated as industrial waste with little market value because of its short shelf life [12]. It contains 34 per cent crude protein, 22.5 per cent crude fiber, 12.7 per cent ether extract, 27.5 per cent nitrogen-free extract and 3.8 per cent ash on dry matter basis [13]. Okara is both a source of energy and protein, serving as excellent feed for ducks and pigs, either fed alone or mixed with rice bran, lime stone and salt to make a more complete supplement. The estimated metabolizable energy (ME) content of Okara is 3388 $\mathrm{Kcal} / \mathrm{kg}$.

The soluble non-starch polysaccharides (NSP), part of carbohydrate rich feeds has an anti-nutritive 
Table-1. Average weekly feed intake ( $\mathrm{g}$ per bird) in broilers.

\begin{tabular}{|c|c|c|c|c|c|c|}
\hline \multirow[t]{2}{*}{ Weeks } & \multirow[b]{2}{*}{$\mathrm{T}_{1}$} & \multirow[b]{2}{*}{$\mathbf{T}_{2}$} & \multicolumn{3}{|c|}{ Treatment groups } & \multirow[t]{2}{*}{ C.D. Value } \\
\hline & & & & $\mathbf{T}_{4}$ & $\mathbf{T}_{5}$ & \\
\hline $1^{\text {st }}$ week & $133.34 \pm 2.69$ & $123.81 \pm 3.41$ & $120.24 \pm 3.29$ & $126.90 \pm 3.65$ & $123.57 \pm 3.53$ & NS \\
\hline $2^{\text {nd }}$ week & $349.29 \pm 6.01$ & $303.57 \pm 8.57$ & $299.05 \pm 7.97$ & $297.14 \pm 8.56$ & $308.34 \pm 8.33$ & NS \\
\hline $3^{\text {rd }}$ week & $689.52 \pm 4.67$ & $805.95 \pm 12.94$ & $681.43 \pm 10.83$ & $705.71 \pm 10.35$ & $760.48 \pm 11.20$ & NS \\
\hline $4^{\text {th }}$ week & $815.81 \pm 8.06^{a}$ & $978.76 \pm 8.16^{b}$ & $1010.81 \pm 7.98^{b}$ & $960.10 \pm 7.39^{\mathrm{ab}}$ & $1108.71 \pm 6.90^{b}$ & $22.28^{\star \star}$ \\
\hline $5^{\text {th }}$ week & $862.24 \pm 5.00^{\mathrm{a}}$ & $833.33 \pm 8.32^{a}$ & $1128.86 \pm 0.40^{b}$ & $1086.91 \pm 0.36^{b}$ & $1169.29 \pm 1.07^{b}$ & $12.64^{\star *}$ \\
\hline $6^{\text {th }}$ week & $1097.91 \pm 7.99^{\mathrm{ab}}$ & $1043.33 \pm 4.27^{\mathrm{a}}$ & $1174.95 \pm 3.70^{\mathrm{bc}}$ & $1204.48 \pm 1.71^{\circ}$ & $1258.38 \pm 2.29^{c}$ & $13.17^{* *}$ \\
\hline \multicolumn{2}{|c|}{$\begin{array}{l}\text { Average total feed consumption } \\
3948.10 \pm 7.60 \\
\text { Average daily feed consumption }\end{array}$} & $4088.76 \pm 8.30$ & $4415.33 \pm 9.44$ & $4381.24 \pm 9.25$ & $4728.76 \pm 10.05$ & NS \\
\hline & $94.00 \pm 20.73$ & $97.35 \pm 22.00$ & $105.13 \pm 26.02$ & $104.32 \pm 25.52$ & $112.59 \pm 27.87$ & NS \\
\hline
\end{tabular}

a,b,c Mean values with different superscripts within a row differ significantly, NS=Non-Significant, $* * P<0.01$

effect in poultry due to modification of the intestinal viscosity and altered intestinal transit time. This consequently reduces rate of diffusion and assimilation of various nutrients. As the viscosity increases, the ability of bird to mix content of feed in gut is drastically impaired. This reduces emulsification of fat, thereby, reducing the total available nutrients to the birds. Secondly, retention of ingesta in gut for longer time will potentiate the proliferation of microbial population leading to increase possibility of secondary infections. The NSP degrading enzyme will minimize such effects of non-starch polysaccharides of feed and will be beneficial for birds. The enzyme lowers the feed cost and help in reducing the environmental pollution by minimizing the waste excretion. Keeping in view the above facts, the present study was done to know the carcass quality and organoleptic tests of broiler birds after feeding Okara meal.

\section{Materials and Methods}

Two hundred twenty (220) day-old broiler chicks (Cobb strain, Venky's Hatcheries Pvt. Ltd., Bokaro) were individually weighed and divided randomly into five treatment groups $\left(\mathrm{T}_{1}, \mathrm{~T}_{2}, \mathrm{~T}_{3}, \mathrm{~T}_{4}\right.$ and $\left.\mathrm{T}_{5}\right)$ consisting of 44 chicks each which was further subdivided into four replicates of 11 chicks. All rations were designed in such a way that they contain all the nutrients as per Bureau of Indian Standard specifications [14] for broiler birds. First group was treated as a control ration $\left(\mathrm{T}_{1}\right)$ containing groundnut cake (GNC). In groups $\mathrm{T}_{2}$ and $\mathrm{T}_{3}$ the GNC of control ration was replaced by Okara meal at 25 and 50 per cent, respectively, on protein equivalent basis. In groups $T_{4}$ and $T_{5}$ the chicks were offered the same diets as in groups $T_{2}$ and $T_{3}$, respectively, but with addition of NSP degrading enzyme (provizyme-bro) @ $50 \mathrm{~g}$ per $100 \mathrm{~kg}$. Equal amount of mineral mixture, common salt and vitamin supplement were added in the ration of all groups. Standard broiler ration (Gold Mohur make) and fresh drinking water and all required vaccine were given to all birds during entire experimentation. All the birds were fed ad libitum. Weighed quantity of feed was offered at 7:00 A.M. in the morning, 1:00 P.M. in afternoon and 6:00 P.M. in the evening.

Ethical approval: This research work has been carried out with the approval of the institutional ethics committee and as per the laws in force at the time of carrying out this work and at the time of sending this paper for publication.

Feed intake: The feed consumption of the experimental birds under each treatment was measured on the replicate group basis at weekly intervals for six weeks. At the end of every week, feed residue and spillage were collected and quantitatively measured for each replicate group to record the net feed intake. On the basis of week wise feed intake, average cumulative feed intake under each group was accordingly calculated.

Body weight gain: All the chicks were wing-banded and their individual body weight was recorded from the each replicate group at weekly intervals from first to sixth week of age to ascertain week wise body weight and body weight gain. The average value of body weight and gain under each treatment group was then calculated. Weight of birds was taken in the morning before offering feed and water to them.

Feed conversion ratio: The feed conversion ratio was calculated as the amount of feed consumed per unit weight gain.

Protein efficiency ratio: The protein efficiency ratio was calculated as the amount of protein consumed per unit weight gain as follows.

Statistical analysis: The data obtained in the present studies were analyzed statistically and subjected to test of significance as per the methods described by Snedecor and Cochran [15] and by using WinStat software system.

\section{Results and Discussion}

The present study was carried out to Study the growth performance of the broiler birds after feeding Okara meal containing with or without NSP degrading enzyme. The feed consumption in each replicates of five groups was recorded daily for a total period of 6 weeks experimental feeding. The differences were statistically non-significant $(P>0.01)$ among the various groups. (Table-1) Average total body weight gain in group $\mathrm{T}_{4}$ showed significant increase as compared to $\mathrm{T}_{1}, \mathrm{~T}_{2}$ and $\mathrm{T}_{5}$, where as $\mathrm{T}_{3}$ and $\mathrm{T}_{4}$ did not differ significantly. Groups $\mathrm{T}_{2}, \mathrm{~T}_{3}$ and $\mathrm{T}_{4}$ also showed 
Table-2. Average body weight gain $(\mathrm{g})$ in broilers.

\begin{tabular}{|c|c|c|c|c|c|c|}
\hline Weeks & $\mathbf{T}_{1}$ & $\mathbf{T}_{2}$ & $\begin{array}{l}\text { Treatment group } \\
\mathrm{T}_{3}\end{array}$ & $\mathbf{T}_{4}$ & $\mathbf{T}_{5}$ & C.D. Value \\
\hline $1^{\text {st }}$ week & $64.21 \pm 0.75^{a}$ & $66.83 \pm 0.87^{\mathrm{ab}}$ & $64.29 \pm 0.91^{a}$ & $69.00 \pm 1.16^{b}$ & $64.98 \pm 1.31^{\mathrm{a}}$ & $2.85^{\star *}$ \\
\hline $2^{\text {nd }}$ week & $130.43 \pm 3.61^{a}$ & $128.00 \pm 2.79^{\mathrm{a}}$ & $138.62 \pm 3.91^{\mathrm{ab}}$ & $146.76 \pm 4.47^{b}$ & $136.29 \pm 4.16^{\mathrm{ab}}$ & $10.68^{\star *}$ \\
\hline $3^{\text {rd }}$ week & $220.48 \pm 4.48^{\mathrm{b}}$ & $218.43 \pm 5.18^{b}$ & $234.90 \pm 7.18^{b c}$ & $243.95 \pm 6.31^{c}$ & $191.62 \pm 6.83^{\mathrm{a}}$ & $16.96^{\star *}$ \\
\hline $4^{\text {th }}$ week & $243.67 \pm 6.83^{a}$ & $291.00 \pm 8.96^{b}$ & $288.62 \pm 12.61^{b}$ & $279.93 \pm 11.97^{b}$ & $286.67 \pm 9.56^{b}$ & $28.45^{\star *}$ \\
\hline $5^{\text {th }}$ week & $338.88 \pm 9.92^{a}$ & $310.52 \pm 9.72^{\mathrm{a}}$ & $333.38 \pm 11.87^{\mathrm{a}}$ & $371.12 \pm 11.76^{b}$ & $335.95 \pm 10.82^{a}$ & $30.27^{* *}$ \\
\hline $\begin{array}{l}6^{\text {th }} \text { week } \\
\text { Average } t\end{array}$ & $\begin{array}{l}427.31 \pm 11.11^{a} \\
\text { y wt. gain }\end{array}$ & $528.43 \pm 21.46^{b c}$ & $568.81 \pm 30.04^{c}$ & $584.14 \pm 19.80^{\circ}$ & $502.57 \pm 25.12^{b}$ & $62.47^{* *}$ \\
\hline Average & $\begin{array}{l}1424.98 \pm 24.93^{a} \\
y \text { wt. gain }\end{array}$ & $1543.21 \pm 35.44^{b c}$ & $1628.62 \pm 49.53^{\mathrm{cd}}$ & $1694.90 \pm 33.88^{d}$ & $1518.07 \pm 45.36^{\mathrm{ab}}$ & $108.25^{\star \star}$ \\
\hline & $33.93 \pm 0.59^{a}$ & $36.74 \pm 0.84^{b c}$ & $38.78 \pm 1.18^{\mathrm{cd}}$ & $40.35 \pm 0.81^{d}$ & $36.14 \pm 1.08^{\mathrm{ab}}$ & $2.57^{\star *}$ \\
\hline
\end{tabular}

$a, b, c$ Mean values with different superscripts within a row differ significantly, NS=Non-Significant, $* * P<0.01$

Table-3. Average feed conversion ratio [feed intake ( $\mathrm{g}) / \mathrm{gain}$ in body weight $(\mathrm{g})$ ] in broilers.

\begin{tabular}{|c|c|c|c|c|c|c|}
\hline \multirow[t]{2}{*}{ Weeks } & \multirow[b]{2}{*}{$\mathbf{T}_{1}$} & \multirow[b]{2}{*}{$\mathbf{T}_{2}$} & \multicolumn{3}{|c|}{ Treatment groups } & \multirow[t]{2}{*}{ C.D. Value } \\
\hline & & & $\mathbf{T}_{3}$ & $\mathbf{T}_{4}$ & $\mathbf{T}_{5}$ & \\
\hline $1^{\text {st }}$ & 2.077 & 1.853 & 1.870 & 1.839 & 1.902 & --- \\
\hline $2^{\text {nd }}$ & 2.678 & 2.372 & 2.157 & 2.025 & 2.262 & --- \\
\hline $3^{\text {rd }}$ & 3.127 & 3.690 & 2.901 & 2.893 & 3.969 & --- \\
\hline $4^{\text {th }}$ & 3.348 & 3.363 & 3.502 & 3.430 & 3.868 & --- \\
\hline $5^{\text {th }}$ & 2.544 & 2.684 & 3.386 & 2.929 & 3.481 & --- \\
\hline $6^{\text {th }}$ & 2.569 & 1.974 & 2.066 & 2.062 & 2.504 & --- \\
\hline Average & $2.724 \pm 0.19$ & $2.656 \pm 0.30$ & $2.647 \pm 0.29$ & $2.530 \pm 0.26$ & $2.997 \pm 0.36$ & NS \\
\hline
\end{tabular}

NS $=$ Non-Significant

Table-4. Average protein efficiency ratio [weight gain ( $\mathrm{g}$ / protein consumed $(\mathrm{g})$ ] in broilers.

\begin{tabular}{|c|c|c|c|c|c|c|}
\hline Weeks & $\mathbf{T}_{1}$ & $\mathbf{T}_{2}$ & $\begin{array}{l}\text { Treatment } \\
\mathbf{T}_{3}\end{array}$ & $\mathbf{T}_{4}$ & $\mathbf{T}_{5}$ & C.D. Value \\
\hline $1^{\text {st }}$ & 2.362 & 2.602 & 2.520 & 2.625 & 2.525 & --- \\
\hline $2^{\text {nd }}$ & 1.831 & 2.033 & 2.185 & 2.384 & 2.123 & --- \\
\hline $3^{\text {rd }}$ & 1.568 & 1.307 & 1.625 & 1.669 & 1.210 & --- \\
\hline $4^{\text {th }}$ & 1.465 & 1.433 & 1.346 & 1.407 & 1.242 & --- \\
\hline $5^{\text {th }}$ & 2.175 & 2.076 & 1.572 & 1.914 & 1.513 & --- \\
\hline $6^{\text {th }}$ & 2.154 & 2.822 & 2.577 & 2.719 & 2.104 & --- \\
\hline Average & $1.926 \pm 0.15$ & $2.046 \pm 0.25$ & $1.971 \pm 0.22$ & $2.120 \pm 0.22$ & $1.786 \pm 0.22$ & NS \\
\hline
\end{tabular}

$\mathrm{NS}=$ Non-Significant

significant increase in body weight as compared to control group while, $\mathrm{T}_{1}$ and $\mathrm{T}_{5}$ did not differ significantly (Table-2). The average total body weight gain and average daily weight gain in birds of group $\mathrm{T}_{4}$ were significantly higher $(P<0.01)$ than birds of other groups except $\mathrm{T}_{3}$ group. It showed that 25 percent replacement of GNC with Okara meal and addition of NSP degrading enzyme had positive effect on growth performance of birds. It might be due to more digestibilities of crude protein moiety of Okara meal and degradation of fibrous portion of the ration by NSP degrading enzyme. It is already reported that as the excess crude fiber of the ration was degraded, digestibility of other nutrients was increased $[16,17]$. Similar result was found [18] by addition by crude enzyme preparation in diets containing Bedford barley in the ration of leghorn chicks. However, the present result does not confirm the findings of Elangovan [19] and Nageswara [20], which might be due to different feed ingredients and different enzymes utilized in their experiments. The increase in weight in broilers of enzyme added group $\mathrm{T}_{4}$ in comparison to their counterpart without enzyme group $\left(T_{2}\right.$ and $\left.T_{3}\right)$ attributed to degradation of NSP in ration, thereby, enhancing the utilization of other nutrients. This result is in corroboration with the findings of Brenes [18] and Oloffs [21].

The feed conversion efficiency differences among the five groups were non-significant $(\mathrm{P}>0.05)$ (Table-3). Further, better results in this respect were noticed on supplementation of NSP degrading enzyme supplement ration $\left(\mathrm{T}_{4}\right)$ group. The present findings are in agreement with the findings of Aletor and Olonimoya [22] in chicks fed processed soybean based diets and Zhu [23]. Non-significant effect of NSP degrading enzyme supplement is in agreement with earlier reports of Elangovan [24] in laying hens and Elangovan [19] in Japanese quails.

The protein efficiency ration values in respect of all the five groups did not differ significantly among themselves $(P>0.05)($ Table-4) The findings indicate that broiler birds in control as well as in four experimental groups utilized the consumed protein for their body weight gain with similar efficiency.

The findings indicated that Okara meal feeding had no adverse effect on growth performance of the broilers. The present findings are also in agreement with the observations of Bajpai and Gupta [25] where 
autoclaved SBM gave similar rate of growth as GNC. Gupta [26] also found that roasted soybean grain had no harmful effect on body weight gain in chicks.

\section{Conclusion}

The findings indicated that 25 percent replacement of GNC with Okara meal and addition of non-starch polysaccharides degrading enzyme had positive effect on growth performance of birds. So, Okara meal feeding had no adverse effect on growth performance of the broilers.

\section{Authors' contribution}

All authors contributed equally.

\section{Acknowledgements}

The authors express their gratitude to the Dean, Ranchi Veterinary College and the Vice-Chancellor, BAU, Kanke, Ranchi, Jharkhand for providing the facilities for conducting this experiment.

\section{Competing interests}

Authors declare that they have no competing interest.

\section{References}

1. Panda, B. and Mohapatra, S.C. (1989) Poultry production.

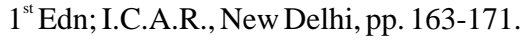

2. Mateos Aparicio, I., Redondo Cuenca, A., Villanueva Suarez, M. J. and Zapata-Revilla, M. A. (2008) Soybean, a promising source of dietary fibre. Nutricion Hospitalaria, 23: 305-312.

3. Tacon, A.G.H. (1993) Feed ingredients for warm water fish: Fish meal and other processed feedstuffs. FAO fisheries Circular NO. 856, Rome, pp. 64.

4. Kim JI, Kang MJ (2009) Soybean health benefits of applications in food. Korea Soybean Digest 26: 1-9.

5. Devi, M. K. A., Gondi, M., Sakthivelu, G., Giridhar, P., Rajasekaran, T., \& Ravishankar, G. A. (2009) Functional attributes of soybean seeds and products, with reference to isoflavone content and antioxidant activity. Food Chemistry, 114(3): 771-776.

6. O'Toole, D.K. (1999) Characteristics and use of okara, the soybean residue from soy milk production. Journal of Agriculture Food Chemistry, 47: 363-371.

7. Shurtleff, W. and Aoyagi, A. (2004) History of soybean fiber products: Okara (soy pulp) and soy bran (ground hulls). Tofu and soymilk production. New age food study, Lafayette, CA, USA.

8. Redondo Cuenca, A., Villanueva Suarez, M. J. and Mateos Aparicio, I. (2008) Soybean seeds and its by-product okara as sources of dietary fiber. Measurement by AOAC and Englyst methods. Food Chemistry, 108: 1099- 1105.

9. Jimenez Escrig, A., Tenorio, M. D., Espinosa Martos, I. and Ruperez, P. (2008) Health promoting effects of a dietary fiber concentrate from the soybean by-product okara in rats. Journal of Agricultural and Food Chemistry, 56: 74957501.

10. Espinosa Martos, I. and Ruperez, P. (2009) Indigestible fraction of okara from soybean: Composition, physico- chemical properties and in vitro fermentability by pure cultures of Lactobacillus acidophilus and Bifidobacterium bifidum. European Food Research and Technology, 228(5): 685- 693

11. Mateos Aparicio, I., Redondo Cuenca, A. and Villanueva Suarez, M. J. (2010) Isolation and characterisation of cell wall polysaccharides from legume by-products: Okara (soymilk residue), pea pod and broad bean pod. Food Chemistry, 122: 339- 345.

12. Ohno, A., Ano, T. and Shoda, M. (1996) Use of soybean curd residue, okara, for the soiled state substrate in production of a lioipeptid antibiotic, iturin A, by Bacillus subtilis NB 22 . Process Biochemistry, 31: 801-806.

13. Farhat, A., Normand, L., Chavez, E.R. and Touchburn, S.P. (1998) Nutrient digestibility in food waste ingredients for Pekin and Muscovy ducks. Poultry science, 77: 1371-1376.

14. BIS specification (1992) Poultry feed specification (4th revision). Bureau of Indian standard, Manak Bhavan, New Delhi. IS: 1374.

15. Snedecor, G.W. and Cochran, W.G. (2004) Statistical Methods. $8^{\text {th }}$ Edn. Oxford and IBH Publishing Co. Pvt. Ltd., Kolkata.

16. Ranjhan, S.K. (1997) Animal Nutrition in Tropics. Vikas Publishing House Pvt. Ltd. New Delhi-2.

17. Shakouri, M.D. and Kermanshahi, H. (2003) Effect of NSP degrading enzyme supplement on the nutrient digestibility of young chickens fed wheat with different viscosities and triticale. J.Agric. Sci. Technol, 5: 105-112.

18. Brenes, A., Smith, M., Guenter, W. and Marquardt R.R. (1993) Effect of enzyme supplementation on the performance and digestive tract size of broiler chickens fed wheat and barley based diets. Poult. Sci., 72 (9): 1731-9.

19. Elangovan, A.V., Mandal, A.B., Praveen K., Toppo, S. and Johari, T.S. (2004b) Effects of enzymes in India diets with varying energy levels on growth and egg production performance of Japanese quail. Sci. Food agric., 84 (15): 2028-2034.

20. Nageswara, A.R., Ramasubbareddy, V., Reddy, A.R. and Kesha Reddy, A.S. (2003) Effect of dietary enzymes supplementation on performance of broilers. Indian J. Anim Nutr., 20 (3):317-323.

21. Oloffs, K., Jeroch, H. and Schoner, F.J. (1999) Efficacy of non-starch polysaccharides hydrolysing enzyme on nutrient digestibility and gross energy convertibility of barley-rye and wheat-rye based diets for laying hens. Arch. Tierernahr., $52(2): 155-65$.

22. Aletor, V.A. and Olonimoya, F.I. (1992) International Center for Agricultural Research in the Dry Areas, P.O. Box No. 5466, Aleppo, Syria.

23. Zhu-Zhong Ke, Wang-Jing, Lei-ZuYu, Zhang-TieYing and Wang-Jian Hua (2005) Effects of exogenous energy on performance, nutrient metabolism and immune function in broilers fed maize-soybean basal diet. Acta-ZoonutrimentaSinica, 17 (4): 41-45.

24. Elangovan, A.V., Deo, C., Mandal, A.B., Singh, D.P., Shrivastav, H.P. and Johari, T.S. (2004a) Effects of enzymes supplementation on production of brown egg type layers. Indian J. Anim. Nutr., 21 (2): 124-126.

25. Bajpai, L.D. and Gupta, B.S. (1971) Utilization of soybean oil meal in chicken diet, Ind. J. Anim. Sci., 40 (5): 125.

26. Gupta, J.J., Yadav, B.P.S. and Verma, A. (1989) Utilisation of damaged soybean grain in broiler ration. Indian J. Poult. Sci., 24 (3): 166-172. 